\section{From the Editor}

With the publication of this, the first issue of volume 2 of Advances in Cement Research, we are pleased to announce that Professor F. P. Glasser has agreed to act as chairman of the Editorial Advisory Board. Professor Glasser has served on the Board since it was formed to launch $A C R$ in October 1987, and has been active in establishing and promoting the journal throughout the world.

We are pleased to welcome a new member to the Editorial Advisory Board: Professor Arnon Bentur of the Building Research Station, Haifa, Israel. A short biography of Professor Bentur is given below. It is hoped that by broadening the Board in this way, the position of $A C R$ as a truly international journal of the fundamentals of cement science will be strengthened.

Nick Clarke, who was Editor of $A C R$ since its launch, has now taken up a new post dealing with books. We wish him well. It is intended to continue to build on the good work started by him, and we look forward to publishing high quality papers from all parts of the world on research and developments in cement science for many years to come.

\title{
New member of the Editorial Advisory Board
}

\begin{abstract}
Arnon Bentur is Associate Professor of Civil Engineering and Deputy Head, National Building Research Institute, at the Technion-Israel Institute of Technology, Haifa, Israel. He also heads the building materials group at that Institute. In the past, he has held teaching and research positions at the University of Illinois, Urbana-Champaign and Purdue University, USA, and the University of British Columbia, Canada. His primary fields of interest include fibrereinforced cements, cement-polymer composites, high-strength concretes, utilization of cementitious byproducts, durability of building materials, interfacial phenomena and microstructure-property relationships in cementitious composites. He is active in various professional committees of the $\mathrm{ACI}$ and RILEM.
\end{abstract}

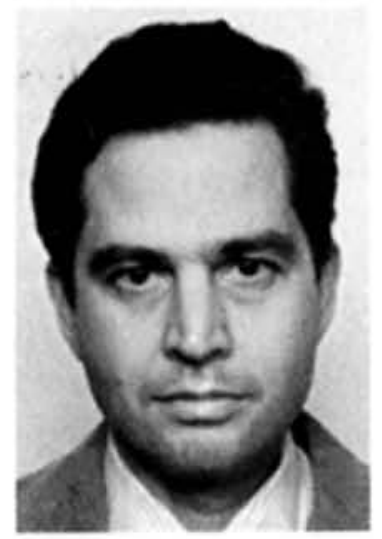

DAVID SANDERS 